\title{
From Stalin to Putin: Russian Strategic Culture in the XXI Century, Its Continuity, and Change
}

\author{
Polina Sinovets \\ Odessa I.I. Mechnikov National University
}

\begin{abstract}
The last two years have attracted the world's attention to Russia. The annexation of Crimea, the hybrid war in Eastern Ukraine, and finally the unexpected interference in Syria-all these actions bring us back to the question of understanding the Russian motivation properly. Generally, it includes the whole interpretation of Russian strategic culture which is based on the research and analysis of the different factors: from literature and history to religion and political nature of the Russian state. Significant attempts to understand Moscow's strategic culture were made by the American experts during the Cold War; therefore the article analyzes the main pillars of Russian strategic culture, its continuity and change in comparison to Soviet times as well as the main reactions of Moscow for what it considers to be a threat.
\end{abstract}

Keywords: strategic culture, Russian identity, security strategy, geopolitical approach

\section{Introduction}

The research of the national strategic culture and its implications for the state's nuclear choice became relevant for the international practice relatively long ago. For the first time, this issue was introduced in the framework of the nuclear narrative by Jack Snyder and concentrated primary on the bureaucracy style politics still later it has been expanded to a wider notion, contributing to the idea of the state's strategic culture. Snyder defined strategic culture as the "set of general beliefs, attitudes and behavioral patterns with regard to nuclear strategy" (Snyder 1977, 5). This definition has become one of the first attempts to interpret the state's nuclear behavior coming from its cultural background; later definitions of this phenomenon deemphasized the nuclear element for the sake of presenting general security approach.

The most modern definition which adds to the Snyder's concept of strategic culture sounds as "set of shared beliefs, assumptions, and models of behavior, derived from common experiences and accepted narratives that shape collective identity and relationships to other groups and which determine appropriate ends and means of achieving national security objectives” (Johnson 2009, 9).

The issue of strategic culture has been researched both at the level of general theory, mostly in the framework of studying deterrence (Gray 1999; Howlett 2006; Knopf 2008; Lantis 2009) as well as the regional dimension. Speaking about Russian strategic culture, it is worthwhile mentioning the contribution of Eitelhuber (2009), D. Adamski (2015), Facon (2012), and Engstrom (2014) who provide a contemporary view on the Russian way of conducting foreign policy and waging war. The significant endeavor in understanding of the

Polina Sinovets, Ph.D., associate professor, Department of International Relations, Odessa I.I. Mechnikov National University, Ukraine; main research field: International Relations and Security Studies. 
Soviet/Russian strategic culture was made by G. Kennan who has determined the main features of Moscow's political identity and its ways of policymaking (Kennan 1947).

Following the definitions, the article aims to explore Russian strategic culture coming from the state's general security beliefs, attitudes, and behavioral patterns, embedded in the international "policy style" of Moscow, thus, giving some basic ideas and formulas on its reasoning.

The methodology of the research involves exploration of national identity, values, norms, and the perceptive lenses of the state. It combines two levels, one of which mostly deals with the research of the public culture in the framework of the nation's historical experience, myths, and narratives. The other level dealing with the political decision-making is mostly researched by such methods as content analysis of the states documents and tracking public rhetoric in accessing the strength of norms.

\section{Russia's Self-perception}

Russia perceives itself as a great state responsible for the special mission in the world which is the reflection of God's commandment, sort of highest truth and justice (Engstrom 2014). This self-perception has deep cultural roots, based on the historical as well as religious and ideological arguments. In particular, Russian mythological narrative assigns itself a role of the Europe's defender and liberator starting from the Mongolian invasion, then Napoleon Bonaparte in XIX century, and finally the liberation of Europe from Hitler during the World War II.

This messianic role is supported by the strong ideology (Moscow as the Third Rome, Russia as the patron and the defender of all Slavs, USSR as the source and the tool of the world socialist revolution, the Russian world). The other thing is that the idea of patronage has always been accompanied by the claim on Russia's inalienable right for the territories of the ones who are defended.

In particular, one of the greatest classical Russian writers Fyodor Dostoyevsky called Russian nation "the God-bearer,” to which the holy city of Constantinople should belong (Dostoyevsky 1994). The writer presented Russia as the leader and the only defender of Orthodoxy, and the Orthodox nations (meaning Slavs who lived at the lands of Ottoman Empire in XIX century), which gives it moral "rights for ancient Tsar grad" (Dostoyevsky 1994).

Sort of spiritual and historic arguments were used by the president Putin in his "Crimea speech," where he justified the annexation of Crimea from Ukraine by the historical and even moral necessity: "In the conscience of people, Crimea has always been the part of Russia. This idea is grounded on the truth and justice..." (Remarks 2014) The idea of Russian messianic role is also supported by such declarations of Russian leader as "we are the strongest as are right," which is very much peculiar to the current Russian rhetoric and ideology.

In this situation, the role of dominating ideology should not be underestimated as it usually shows not only self-perception of the state, but its perception of the world order and state of relationship between Russia and the others.

\section{The Russian Vision of the World Order}

One of the fundamental elements of the Russian worldview in the vision of the world is the spirit of political realism. According to Moscow's perception, the world has its structure and division for the spheres of influence between Russia and the West. 
Coming from the Cold War mentality, it accepts permanent struggle between rivals, still this struggle should take place upon certain rules, drawn as the result of the World War II. This idea which became the cornerstone of Yalta-Potsdam international system gave Russians sort of stability assurances as for the spheres of influence or buffer zones whereas Anti-Ballistic Missile Treaty of 1972 gave certain assurances for strategic stability. The erosion of Yalta-Potsdam system (as well as the withdrawal of the United States from the ABM Treaty in 2001) meant the destruction of this stability and the transformation of the struggle based on rules into no-rule struggle. The understanding of this fact makes Russian authorities to be quite anxious. "The main thing is to build such competition (of states) in the framework of certain political, legal, and moral norms and rules, declared President Putin in his Valdai speech 2015. Or this rivalry is fraught with vigorous crisis and dramatic disruptions" (Valdai Speech, 2015). Therefore, the annexation of Crimea as well as the interference of Russia into Syria was presented as the result of the fact that the West didn't follow the traditional spheres of influence and has interfered Russian traditional domain.

In this regard, the international arena is perceived by Russia as the battlefield with a "zero sum" game, meaning that any victory of the West (such as in Kosovo, in Iraq or Libya) is the Russian lose and vice versa, so the Crimea annexation is interpreted as Russian victory. The current conflict in Ukrainian, Donbass is regarded as sort of the battle in process. In particular Sergey Glaziev, the adviser of the President Putin on economic integration sees the European choice of Ukraine as the result of the Western crusades to the East, the aim of which is to defeat Russia. "Ukrainian Nazism is the artificial creation of the antihuman ideology, which has been cultivated at the West for already a couple of centuries."

In general, the West (more precisely the United States) is presented as the main rival of Russia, namely the "Evil" who tries to undermine Moscow's positions in the world.

The complex of the besieged fortress was first mentioned by Lenin and then underlined by George Kennan, speaking about the efforts of Soviet authorities to present the "outside world as hostile.” Kennan explained it by the attempts of the Soviet authorities to maintain "the dictatorial authority at home" (Kennan 1947, 575).

Still, coming back to the modern situation and the Russian official documents, we can find sort of stable continuity in Russian perception of the West. In particular, the "National Security Strategy," adopted by the President's order on the 31st of December 2015 mentioned the "position of the West, aimed at the creation of the hotbed of tension in the Eurasian space,” which contradicts Russian interests (National Security Strategy, 2015). The main aim of the United States is usually seen as "to destroy strategic balance, to change the balance of power in such a way not just to dominate but to dictate their will to anyone” (Valdai Speech, 2015). The dictatorship of the West seems to be one of the main fears of Russia, then.

\section{Russian Threat-Perception and Ways of Enhancing National Security}

The explanation of the mentioned anxiety over the actions of the West can be also found in Russian traditional threat perception which is based on the deep feeling of insecurity and generally geopolitical interpretation of the international affairs. In particular, despite the fact that Russian territory is enormous, the strategic depth of its European part is not. Russia has regularly been attacked or invaded by different enemies (Tatars, Poles, French, and Germans) and often from the West. Russia thus seeks buffer zones, not only with tanks but also with states (Facon 2014).

Russians are still very fond of geopolitical concepts of Mackinder, who defined the Eurasia as "heartland" or strategic territory, the possession of which can give the key for the world dominance (Eitelhuber 2009, 8). 
Therefore, Moscow has always kept the idea that as soon as Russia gets weaker (which happens, losing traditional buffer zones such as Ukraine when NATO approaching Russian borders), they might be invaded by the West ( the United States, NATO etc.), striving for the world dominance.

To avoid this grave perspective, Russia used to rely on the huge military power. This was started by the Russian Empire, having a very strong military element in its culture, and then kept by the Soviet Union and now is developed by the modern Russia as a nuclear superpower. Sergey Karaganov, the Head of the Council on Foreign and Defense Policy, calls nuclear weapons “something, sent by God to save humankind,” adding that "For the first time in history nothing threatens Russia in the region-due to nuclear weapons and lack of contradictions with other states” (Karaganov 2013).

Russian Orthodox Church, which serves today as "the right hand" of the political regime in Russia accepts nuclear deterrence in a spirit of the so-called "Russian Doctrine," or nationalist worldview, which is based on the idea of Russian consolidation and confrontation with the West. One can also refer to the words of Egor Kholmogorov, a journalist, philosopher, former editor of the "Edinaya Rossiya" official website, and author of the "Atomic Orthodoxy" concept: "In order to fulfill this mission successfully (to approach God), Russia cannot be an Orthodox state only; it should be a powerful state so that nobody and no weapon could silence our testimony of Christ" (Engstrom 2014). The main principle of the "Atomic Orthodoxy" idea, according to Holmogorov, is that "to stay Orthodox Russia should be a strong nuclear power and to stay a nuclear power it should be Orthodox" (Engstrom 2014). This notion Holmogorov takes from the issue of nuclear parity ("atomic clinch”), which not only prevents states from waging war, but brings their rivalry into the mental and spiritual arena. That is why, together with a traditional military defense, the Russian State has to protect the nation by conceptual means, to protect it from mental threats. Translating this notion to practical life, nuclear weapons are destined to deter any kind of Western military interference into the Russian fight against the evil forces domestically (which is the subject of the New Military Doctrine-2014, which is concerned with the result of the informational warfare and the activities of foreign special services in Russia aimed at undermining the regime) as well as in the near abroad. This notion perfectly fits with Georgia as well as Ukraine, both of which have been regarded as proxy battlegrounds for Russia’s ideological fight with the West.

\section{The "Russian Style" of Security Policy}

The last point brings us to the Russian style in national security or "behavioral patterns" according to Snyder whereas the main goal is to answer the question on what qualities should not be disregarded in communicating with Russia successfully. Here it is worthwhile mentioning the following features:

(1) High level of secretiveness and duplicity. These qualities were visible in the Soviet military strategy, when the official peace-building initiatives of 1960s were accompanied by the so-called "Sokolovsky doctrine," which supposed to use nuclear weapons preemptively. In times when the USSR clandestinely stressed war-fighting strategy_-preemption, victory, civil defense the Soviet minister of Foreign Affairs Gromyko said that "the world long ago reached the stage when the continuation of arms race became madness" (Snyder 1977, 10). George Kennan underlined the hypocritical character of the Soviet policy style, saying that "truth is not a constant but actually created for all intents and purposes, by the Soviet leaders themselves" (Kennan 1947, 573).

To certain extent, the current policy trends are following the tradition. In particular, the "National security strategy” of 2015 presents the world on Moscow's manner, where Russia is surrounded by enemies, whose 
special services are functioning even inside the state to erode the stability of the regime “... undermining sovereignty and territorial integrity of Russian Federation” (Military Doctrine, 2014). Therefore, manipulating with information is one of the oldest, powerful, and successful tools of Kremlin in its internal as well as the external policy.

(2) Stratagem as the main tool of not only military, but also a political style of Moscow. It has become one of the most important military tools of Russian army very long ago, being often practiced by Suvorov, or in the Northern War and during the Napoleonic wars. Admiring general Kutuzov, Suvorov said that he was so smart and cunning that even “De Ribas won’t deceive him” (Lobov 2001).

To some extent, the stratagem makes Russian policy as well as strategy flexible enough to avoid direct confrontation. Kennan said that Soviet leaders "have no compunction about retreating in the face of superior force," of course only in the situation when it does not threaten losing their face. According to Snyder, "Soviet strategy has a reputation of being reckless, but it is the strategy of minimizing risks" (Snyder 1947, 15), the quality which is still viable and this is quite visible on the example of the conflict with Turkey over the Russian plane, being shut in Syria this year. Putin preferred to impose economic sanctions, restraining mostly his own people instead of starting military confrontation with NATO member. On the other hand, the ability to back down in some cases does not mean that Moscow is ready to abandon its plans; it is just changing the tools or the itinerary of reaching them. Citing Kennan, "its political action is a fluid stream which moves constantly wherever it is permitted to move toward a given goal” (Kennan 1947, 574). In fact, this quality is demonstrated by the modern Russian political strategy, trying to keep its buffer states by any means - from energy tools in the first decade of 2000s up to the hybrid war activities during the recent years.

(3) Victorious character of the Russian strategy. It has become the result of the qualities, mentioned above, still adds something to the portrait of modern Russia.

In particular, most Soviet military strategists as well as the officials (from Malinovsky to Sokolovsky) always underlined the necessity to defeat the aggressor decisively if war becomes the reality. Coming back to current situation, it is worthwhile referring to Dmitry Adamsky, who keeps the opinion that Russian "new generation warfare" is different from the hybrid war just because of the fact that it is very much oriented on victory, but not the war as a tool of destabilization (Adamsky 2015, 36).

In this sense, any human losses are not significant for Russia. During the World War II, the losses of USSR were almost 10 times higher than by Germany, and in this sense, Zhukov's story how Soviets were demining mine fields sounds quite representative. In particular, at first Soviets sent the infantry to track mines by the price of their lives, then followed sappers and finally the expensive military equipment appeared (Sokolov 2009). Making the projection for the current situation, the insensitivity of Russia towards sanctions to some extent is defined by the fact that Russian people are ready to sacrifice for the glory of their state, at least the annexation of Crimea (which caused major economic sanctions) is supported by the $87 \%$ of the population (Shevtsova 2015).

\section{Conclusions}

Coming to the conclusion, it is worthwhile mentioning that the article does not claim to present the detailed portrait of Russian strategic culture, but aimed at answering the questions usually important for the successful interaction with Russia as a partner or even as a rival. 
Summing up, it is necessary to underline that Russia has a mentality of a great state, used to power projection and having a high feeling of vulnerability. To some extent, both categories are interdependent, as the necessity to surround itself with a belt of the buffer states derives from Russian high feeling of insecurity, which gives a good soil for aggravation of its "besieged fortress complex.” Most often, this aggravation happens as the result of combination of the internal challenges with the external pressure when the world order changes, ruining the former more or less stable rules of co-existence. Therefore, one of the biggest Russian fears is the lack of stability which causes changes in international environment. In such situations, Russia tries to keep for its traditional tools of influence, in particular its hard power, which is often associated by the state with the idea of Russian greatness and even sovereignty.

Here, it is worthwhile mentioning that the idea of the state greatness is important not only for the Russian political elites who are ready to sacrifice with the wealth of the nation, but is also traditionally popular among the people, who are ready to sacrifice with many things for the sake of the "great Russia."

The important thing is to understand that in spite of the high role of the hard power in Russian policy the authorities usually stay rational, being able to react flexibly for any strong obstacle on their way. Usually, Russia is inclined for a reckless behavior only when it perceives that its vital interests are at stake.

Those interests are most often formulated in such official state documents as Military Doctrine and National Security Strategy and usually implied in the "red lines" Russia often tries to draw for the West. In particular, it includes any pro-Western changes in the states-former members of the Soviet Union, as well as the approximation of the NATO military structures closer to Russian borders. Also, speaking about the possibilities of deterrence, it is worth to remember that any unpredictable actions which risk the face of Kremlin might cause its swift and aggressive emotional response and can undermine deterrence. At the same time, it does not mean that any coherent and firm actions of the West to demonstrate its credibility and resolve defending its interest in the important regions will not be successful.

\section{Works Cited}

Adamsky, Dmitry. “Cross-Domain Coercion: The Current Russian Art of Strategy.” Proliferation Papers. November 2015. $<$ https://www.ifri.org/sites/default/files/atoms/files/pp54adamsky.pdf>.

Dostoyevsky, Fyodor. A Writer's Diar: y1877-1881. Evanston, Illinois: Northwestern University Press, 1994.

Eitelhuber, Norbert. “The Russian Bear: Russian Strategic Culture and What It Implies for the West.” The Quarterly Journal 9.1 (2009): 1-28.

Engstrom, Maria. “Contemporary Russian Messianism and New Russian Foreign Policy.” Contemporary Security Policy 35.3 (2014): 353-79.

Facon, Isabelle. “The Russian Way of War: In Crisis?” The Oxford Handbook of War. Oxford: Oxford University Press, 2012.

Gray, Colin. “Strategic Culture as Context: The First Generation of Theory Strikes Back.” Review of International Studies 25.1 (1999): 49-69.

Howlett, Darryl. The Future of Strategic Culture. Comparative Strategic Cultures Curriculum. Prepared for Defense Threat Reduction Agency Advanced Systems and Concepts Office: SAIC, 31 October, 2006.

---. Interview. Liliya Shevtsova. 25 December, 2015. <http://newrezume.org/news/2015-12-25-12374>.

Karaganov, Sergey. "Yadernoe orushie—eto nechto, poslannoe nam Vsevyshnim.” Rossia V Globalnoy Politike. February 23, 2013. <http://www.globalaffairs.ru/pubcol/Yadernoe-oruzhie--eto-nechto-poslannoe-nam-Vsevyshnim-15855>.

Knopf, Jeffrey W. "Wrestling with Deterrence: Bush Administration Strategy after 9/11.” Contemporary Security Policy 29.2 (2008): 229-65.

Lantis, Jeffrey. "Strategic Culture and Tailored Deterrence: Bridging the Gap between Theory and Practice.” Contemporary Security Policy 30.3 (2009): 467-85. 
Lobov, Vladimir. Voyennaya hitrost (Military Stratagem). Moskva: Logos, 2001.

---. Obrasheniye Presidenta Rossiyskoy Feredetsii, 18 marta 2014 goda (Remarks of the President of the Russian Federation). $<$ http://kremlin.ru/events/president/news/20603>.

Snyder, Jack. The Soviet Strategic Culture: Implications for Limited Nuclear Operations. A Force Project Air Report, prepared for the United States Air Force, Santa Monica: RAND, 1977.

Sokolov, Boris. "How to Calculate Human Losses during the Second World War.” Journal of Slavic Military Studies 22.3 (2009): 437-58.

---. Strategic Culture and Weapons of Mass Destruction. Eds. J. Johnson, K. Kartchner, and J. Larsen. NY: Palgrave McMillan, 2009.

---. Strategiya Natsionalnoy Bezopasnosti Rossiyskoy Federatsii (National Security Strategy of Russian Federation). 31 December, 2015. <http://kremlin.ru/acts/bank/40391>.

---. Voyennaya Doktrina Rossiyskoy Federatsii (Military Doctrine of the Russian Federation). December $26,2014$. $<$ http://static.kremlin.ru/media/events/files/41d527556bec8deb3530.pdf>.

X. [G. Kennan]. “The Sources of Soviet Conduct.” Foreign Affairs 25 (1947): 566-82.

---. Zasedaniye mezhdunarodnogo discussionnogo kluba Valdai (The Meeting of the International Valdai Club). November 22, 2015. <http://kremlin.ru/events/president/news/50548>. 